\title{
Genetic interrelationships of North American populations of giant liver fluke Fascioloides magna
}

\author{
Eva Bazsalovicsová1, Ivica Králová-Hromadová ${ }^{*}$, Jan Štefka², Gabriel Minárik, ${ }^{3,4}$ Silvia Bokorová ${ }^{3}$ and Margo Pybus ${ }^{5}$
}

\begin{abstract}
Background: Population structure and genetic interrelationships of giant liver fluke Fascioloides magna from all enzootic North American regions were revealed in close relation with geographical distribution of its obligate definitive cervid hosts for the first time.

Methods: Variable fragments of the mitochondrial cytochrome c oxidase subunit I (cox1; 384 bp) and nicotinamide dehydrogenase subunit I (nad1; $405 \mathrm{bp}$ ) were applied as a tool. The concatenated data set of both cox 1 and nad 1 sequences (789 bp) contained 222 sequences that resulted in 50 haplotypes. Genetic data were analysed using Bayesian Inference (BI), Maximum Likelihood (ML) and Analysis of Molecular Variance (AMOVA).

Results: Phylogenetic analysis revealed two major clades of F. magna, which separated the parasite into western and eastern populations. Western populations included samples from Rocky Mountain trench (Alberta) and northern Pacific coast (British Columbia and Oregon), whereas, the eastern populations were represented by individuals from the Great Lakes region (Minnesota), Gulf coast, lower Mississippi, and southern Atlantic seaboard region (Mississippi, Louisiana, South Carolina, Georgia, Florida) and northern Quebec and Labrador. Haplotype network and results of AMOVA analysis confirmed explicit genetic separation of western and eastern populations of the parasite that suggests long term historical isolation of F. magna populations.

Conclusion: The genetic makeup of the parasite's populations correlates with data on historical distribution of its hosts. Based on the mitochondrial data there are no signs of host specificity of $F$. magna adults towards any definitive host species; the detected haplotypes of giant liver fluke are shared amongst several host species in adjacent populations.
\end{abstract}

Keywords: Trematoda, Fasciolidae, Mitochondrial DNA, Cytochrome c oxidase, Nicotinamide dehydrogenase, Spatial distribution

\section{Background}

Spatial distribution of parasites is closely coupled with distribution of their hosts; parasites require suitable hosts for nutrients and other resources, and thus they cannot occur in territories where susceptible hosts are absent. Therefore, the maximum geographical range of a parasite must equal the combined ranges of its hosts. The hosts also represent the only mean of dispersal for the majority of parasitic taxa and in the case of parasites with multi-host lifecycles, the parasite's dispersal is driven

\footnotetext{
* Correspondence: hromadova@saske.sk

'Institute of Parasitology, Slovak Academy of Sciences, Hlinkova 3, 04001 Košice, Slovakia

Full list of author information is available at the end of the article
}

by its most mobile host. Furthermore, geographical distribution and relationships of the parasites of terrestrial hosts may be affected by historical contractions and expansions of their hosts' distribution, including recent bottlenecks caused by humans $[1,2]$. On the larger scale, a positive relationship between host and parasite species richness is inevitable and generally supported, since most host species harbour at least one host specific parasite [3].

Influence of hosts and parasites on their respective biodiversity is of particular interest, since each partner in a host-parasite association potentially exerts a selective pressure on the other [4]. The relationship between host and parasite represents an intimate interaction between at least two genetic systems [5]. The host- 
parasite interaction is based on subtle interplay between parasite survival strategies and host defence mechanisms [5]. Revealing population genetic structure and host specificity of the parasitic species in question is the first natural step towards understanding the underlying processes of natural selection.

Giant liver fluke, Fascioloides magna, represents a very interesting parasitic model characterized by a wide spectrum of intermediate and definitive hosts, large spatial distribution, potential to colonize new territories and adapt to new host species. It parasitizes a wide range of definitive ruminant hosts, especially cervids. The fluke has a strong predilection to liver parenchyma where it is localized in thin-walled fibrous pseudocysts. It is generally accepted that $F$. magna is of North American origin and may have co-evolved with ancestral cervids, Odocoileus spp. [6]. Currently, F. magna is enzootic in five major areas across the United States and Canada: (1) the northern Pacific coast, (2) the Rocky Mountain trench, (3) northern Quebec and Labrador, (4) the Great Lakes region, and (5) Gulf coast, lower Mississippi, and southern Atlantic seaboard.

Concerning the host spectrum of giant liver fluke in North America, a variety of free-living (e.g., wapiti Cervus elaphus canadensis, white-tailed deer Odocoileus virginianus, caribou Rangifer tarandus, black-tailed deer Odocoileus hemionus columbianus and mule deer Odocoileus hemionus hemionus) and domestic ruminants (cattle Bos taurus, goat Capra hircus, and sheep Ovis aries) are known to be susceptible to F. magna infection but only white-tailed deer, caribou, and wapiti contribute significantly to maintaining its population [6]. It is assumed that the parasite was widespread in white-tailed deer in major wetland habitats throughout North America; however, the interrelationships of this host with $F$. magna were finely tuned due to low number of flukes within individual deer. On the other hand, potential for translocation of liver flukes in wapiti is higher due to increased F. magna egg production and subsequent release to the environment [6].

In Europe in the $19^{\text {th }}$ and $20^{\text {th }}$ centuries, game keeping and hunting had a tendency to increase the biodiversity of game species in local hunting grounds by extensive introduction and restocking of "exotic" game. As a consequence of the introduction of wapiti from North America, the giant liver fluke was unintentionally introduced to Europe, where it established three natural foci of infection; (1) northern Italy, (2) Czech Republic and south-western Poland, and (3) Danube floodplain forests (for review see [7]). In Europe, F. magna is considered to be an introduced invasive species with high potential to colonize new geographic territories and establish local populations. In particular, the Danube floodplain forests represent an expanding natural focus of fascioloidosis with inevitable spread of the parasite down the Danube River [8]. In Europe, giant liver fluke has shown high capability to adapt to different intermediate aquatic snail hosts, such as species of Galba, Lymnaea, and Radix [9-11] and definitive ruminant species, in particular red deer Cervus elaphus elaphus, roe deer Capreolus capreolus, and fallow deer Dama dama [10, 12].

The origin of European populations of F. magna and the subsequent course of colonisation and migratory routes of this alien parasite in Europe recently were unravelled [13]. Phylogenetic analyses based on concatenated $\operatorname{cox} 1+$ nad 1 datasets revealed two genetically separated clades of European F. magna. The Italian population represented one phylogenetic clade while the second one included populations from the Czech focus and the Danube floodplain forests. Results clearly indicated that $F$. magna was introduced from North America to Europe at least twice; first to Italy and independently to the Czech Republic. As comparative samples, several F. magna specimens from North America were included in the abovementioned work. The overall analysis of North American and European giant liver fluke populations clearly confirmed a western North American origin of the Italian population; these flukes clustered with specimens from Alberta (Canada) and Oregon (USA). On the other hand, representatives of the Czech Republic and Danube floodplain forests displayed close genetic relationships with parasites from the south-eastern USA. These data showed for the first time relatively high genetic molecular diversity of North American F. magna individuals [13]. However, the limited number of the flukes from North America did not cover all five enzootic regions and were insufficient for detailed phylogeographic analysis. Therefore, the aim of the current work was to determine population structure of F. magna from a more extensive dataset including all five enzootic North American regions using previously applied mitochondrial cox 1 and nad 1 molecular markers $[13,14]$ in order to reveal genetic interrelationships of giant liver fluke on its original continent. Results were assessed in relation to the geographical distribution of its obligate definitive cervid hosts.

\section{Methods}

\section{Parasite samples}

A total of 248 F. magna from 37 livers originating from all five North American enzootic regions were included in the analysis (Table 1). From the 248 parasites, 140 samples were newly analysed, while the remaining ones were already included in our previous analysis [13] (see Table 1, superscript a). Flukes were isolated directly from parenchymatous cysts and immediately rinsed in PBS buffer and fixed in $96 \%$ ethanol.

Flukes from the enzootic region of northern Quebec and Labrador (NQL) were collected from muskox (Ovibos 
Table 1 Details on Fascioloides magna specimens analyzed in the current study

Enzootic region/ Country/province (state) Locality Geographical

\section{Region code}

Northern Quebec and Labrador/NQL
Canada/Quebec (QC)

Tasiujaq

coordinates

$58^{\circ} 44^{\prime} \mathrm{N}, 70^{\circ} 02^{\prime} \mathrm{W}$

$58^{\circ} 06^{\prime} \mathrm{N}, 68^{\circ} 23^{\prime} \mathrm{W}$

(muskox)

Host

Liver code Number of flukes

6

Northern Quebec and
Labrador/NQL

Canada/ Newfoundland and Labrador (NL)

northern Labrador at Nashaupi River

$53^{\circ} 55^{\prime} \mathrm{N}, 60^{\circ} 44^{\prime} \mathrm{W}$

Rocky Mountains trench/RMT

Canada/Alberta (AB)

Banff National Park

$51^{\circ} 12^{\prime} \mathrm{N}, 115^{\circ} 35^{\prime} \mathrm{W}$

QC-1

QC-2

QC-3

7

QC-4

QC-4 2

(2)

Northern Pacific Coast/NPC

Canada/British

Columbia (BC)

Vancouver Island

$49^{\circ} 00^{\prime} \mathrm{N}, 127^{\circ} 00^{\prime} \mathrm{W}$

$44^{\circ} 56^{\prime} \mathrm{N}, 123^{\circ} 02^{\prime} \mathrm{W}$

Coast/NPC

USA/Oregon (OR) Salem

$47^{\circ} 40^{\prime} \mathrm{N}, 96^{\circ} 00^{\prime} \mathrm{W}$

Erskine

Region/GLR

USA/Minnesota (MN)

Hibbing

Gulf coast, Lower Mississippi and Southern Atlantic Seaboard/SAS

\section{USA/Mississippi (MS)}

St. Catherine NWR

$32^{\circ} 32^{\prime} \mathrm{N}, 91^{\circ} 22^{\prime} \mathrm{W}$

Cervus elaphus

canadensis

(wapiti; Rocky

Mountain elk)

subtotal

Rangifer tarandus

subtotal

Cervus elaphus roosvelti

(wapiti; Roosevelt elk)

NL-1

19

(caribou)

$\mathrm{NL}-2$

2

$\mathrm{NL}-3$

3

AB-2

AB-5

AB-8

AB-11

$A B-1$

AB-4

AB-6

$A B-8$

AB-9

$A B-11$

AB-15

9

BC-1

$B C-2$

$B C-3$

BC-4

BC-5

subtotal

Odocoileus hemionus

5

columbianus

(black-tailed deer)

subtotal

Odocoileus virginianus

(white-tailed deer)

subtotal

1 or $>1^{b}$

28

C. e. canadensis

MS-35

MS-35

(wapiti; Rocky Mountain elk)

MS-34

subtotal

2

C. e. canadensis

LA-38

LA-39

LA-38

LA-39

2

2

2

6

23

1

17

9

$37^{a}$

$1^{\text {a }}$

$1^{\text {a }}$

$5^{a}$

$8^{\mathrm{a}}$

$5^{a}$

$1^{a}$

108

8

1

1

2

3

15

1

$4^{a}$

5

$28^{a}$

Mountain elk)

subtotal 
Table 1 Details on Fascioloides magna specimens analyzed in the current study (Continued)

\begin{tabular}{|c|c|c|c|c|c|c|}
\hline \multirow{7}{*}{$\begin{array}{l}\text { Gulf coast, Lower } \\
\text { Mississippi and Southern } \\
\text { Atlantic Seaboard/SAS }\end{array}$} & \multirow{7}{*}{$\begin{array}{l}\text { USA/South } \\
\text { Carolina (SC) }\end{array}$} & \multirow[t]{7}{*}{ Savannah River Site } & \multirow[t]{7}{*}{$34^{\circ} 26^{\prime} \mathrm{N}, 82^{\circ} 51 \mathrm{~W}$} & O. virginianus & SC-40 & 5 \\
\hline & & & & \multirow[t]{5}{*}{ (white-tailed deer) } & SC-41 & 5 \\
\hline & & & & & SC-42 & 8 \\
\hline & & & & & SC-43 & 7 \\
\hline & & & & & SC-44 & 2 \\
\hline & & & & & SC-45 & 2 \\
\hline & & & & subtotal & 6 & 29 \\
\hline \multirow{3}{*}{$\begin{array}{l}\text { Gulf coast, Lower } \\
\text { Mississippi and Southern } \\
\text { Atlantic Seaboard/SAS }\end{array}$} & \multirow[t]{3}{*}{ USA/Georgia (GA) } & \multirow[t]{3}{*}{ Wilkinson } & \multirow[t]{3}{*}{$32^{\circ} 48^{\prime} \mathrm{N}, 83^{\circ} 09^{\prime} \mathrm{W}$} & C. e. canadensis & GA-31 & 4 \\
\hline & & & & $\begin{array}{l}\text { (wapiti; Rocky } \\
\text { Mountain elk) }\end{array}$ & GA-32 & $1^{a}$ \\
\hline & & & & subtotal & 2 & 5 \\
\hline \multirow{6}{*}{$\begin{array}{l}\text { Gulf coast, Lower } \\
\text { Mississippi and Southern } \\
\text { Atlantic Seaboard/SAS }\end{array}$} & \multirow[t]{6}{*}{ USA/Florida (FL) } & \multirow{6}{*}{$\begin{array}{l}\text { White Oak } \\
\text { plantation }\end{array}$} & \multirow[t]{6}{*}{$30^{\circ} 44^{\prime} \mathrm{N}, 81^{\circ} 45^{\prime} \mathrm{W}$} & C. e. canadensis & FL-36 & 2 \\
\hline & & & & (wapiti; Rocky & FL-37 & 6 \\
\hline & & & & Mountain elk) & FL-36 & $2^{a}$ \\
\hline & & & & & $\mathrm{FL}-37$ & $8^{a}$ \\
\hline & & & & subtotal & 2 & 18 \\
\hline & & & & TOTAL & 37 or $>37^{b}$ & 248 \\
\hline
\end{tabular}

${ }^{\mathrm{a}}$ Sequences published by Králová-Hromadová et al. [13]; ${ }^{\mathrm{b}} \mathrm{F}$. magna specimens from Minnesota were not identified by liver sample or exact sampling site; NWR, National Wildlife Refuge

moschatus) and caribou (Rangifer tarandus), while specimens from the Rocky Mountain trench (RMT) originated from wapiti. In the northern Pacific coast (NPC), F. magna samples were isolated from Roosevelt elk (Cervus elaphus roosevelti) and black-tailed deer. In Minnesota, belonging to the Great Lakes region (GLR), all flukes came from white-tailed deer. Finally, the Gulf coast, lower Mississippi, and southern Atlantic seaboard (SAS) enzootic region was represented by $F$. magna from wapiti and white-tailed deer; in particular flukes were obtained from US states of Mississippi (MS), Louisiana (LA), Georgia (GA), Florida (FL), and South Carolina (SC).

\section{DNA isolation, PCR amplification and sequencing}

Genomic DNA was isolated from $20 \mathrm{mg}$ of adult flukes using phenol:chlorophorm:isoamyl alcohol extraction and ethanol precipitation [14]. In order to completely remove remaining PCR inhibitors, such as divalent cations and proteins, two additional wash steps using the QIAamp ${ }^{\oplus}$ DNA Kit (QIAGEN, Hilden, Germany) were employed in the DNA purification procedure. Finally, genomic DNA was diluted in deionised water and stored at $-20{ }^{\circ} \mathrm{C}$.

For amplification and sequencing of partial mitochondrial cytochrome $c$ oxidase subunit I ( $\operatorname{cox} 1 ; 384 \mathrm{bp})$ and nicotinamide dehydrogenase subunit I (nad1; $405 \mathrm{bp}$ ), the previously designed primers and PCR conditions were applied $[13,14]$. The PCR products were loaded on the $1 \%$ agarose gel and purified either using the Wizard PCR purification Kit (Promega, Madison, Wisconsin) or with exonuclease I and shrimp alkaline phosphatase
[15]. Sequencing was performed using an automatic genetic analyzer Applied Biosystems 3130xl (Applied Biosystems, Foster City, California) and BigDye Terminator v3.1 Cycle sequencing kit (Applied Biosystems). Contiguous sequences were assembled and inspected for errors using Geneious version 7.1.7 (Biomatters, Auckland, New Zealand). The translation into the amino-acid sequence was performed according to the trematode mitochondrial code $[16,17]$. Concatenation of cox 1 and nad 1 datasets was performed in SeaView 4.2 [18]. Distribution maps showing sampling locations were prepared using the Inkscape version 0.485.0 (free download from https://inkscape.org).

\section{Computational, statistical and phylogenetic analyses of genetic data}

Phylogenetic reconstruction of the relationships between mtDNA haplotypes was performed using concatenated data with Maximum Likelihood algorithms (ML) in PhyML 3.0 [19] and Bayesian Inference (BI) in MrBayes 3.2.3 [20]. We used a concatenated dataset based on the experience from a previous analysis [13], where individual gene networks did not provide conflicting patterns. Statistical support of the resulting topologies was obtained by 1000 bootstrap replications in PhyML. MrBayes was run in two parallel runs with four chains each and two million MCMC replications sampled every 1000 generations. Twenty percent of the run was discarded as burn-in. Convergence of the parameters obtained in the two runs was inspected in Tracer 1.6 (http://tree.bio.ed.ac.uk/software/tracer). Model of molecular evolution for the BI analysis was selected in 
PartitionFinder [21] allowing separate parameter estimation for each gene and each codon position. HKY + I model was selected for the first two codon positions, whereas GTR + G was selected for the third position. TN93 model was selected in PartitionFinder for the PhyML analysis, where the usage of separate models for codon positions is not supported. Phylogenetic trees were rooted using $\operatorname{cox} 1$ and nad 1 sequences of the closest available relative, Fasciola hepatica (GenBank Accession No. NC002546). The topology used to position a root for the trees from the ML and BI analyses was obtained in PhyML by a ML analysis of translated amino acid sequences under the LG model. Amino acid sequence analysis was used due to a relatively deep level of genetic variation between the two genera, which created a very long branch when analysed in the DNA mode.

Genealogical information contained in the two mtDNA genes was visualized using haplotype network in the software TCS 1.21 [22]. To explore the effect of geographical distribution on the structuring of the populations, analysis of molecular variance (AMOVA) was performed using the concatenated dataset in Arlequin 3.5.1.2 [23]. The hierarchical grouping of samples for the analysis was designed in two alternative schemes: 1) populations were grouped into five enzootic foci [6] of F. magna (see Table 1); 2) population groups were reorganized into six sets to better reflect the distribution and sharing of haplotypes between populations seen in TCS network. Regions in the north-west (NPC and RMT) were pooled, whereas the SAS region in the south-east was divided into three separate groups (Table 2). Significance of the obtained results was tested with 10,000 permutations of the data. Analyses of haplotype diversity $(H d)$, nucleotide diversity $(P i)$ and neutrality tests (Tajima's D, Fu and Li's D, Fu and Li's F) for population sets used in the second AMOVA analysis were calculated for concatenated data in DNASP 5.10.1 [24]. Significance of the neutrality tests was obtained with 10,000 coalescent simulations.

\section{Results}

The analysis of 384 bp cox 1 mtDNA fragment (128 amino acids, aa) and 405 bp nad 1 fragment (134 aa + stop codon) revealed 32 cox 1 (CO1-Ha) and $28 \operatorname{nad} 1$ (ND1-Ha) mitochondrial haplotypes (Table 3). The numbering of $\mathrm{CO} 1-\mathrm{Ha}$ and $\mathrm{ND} 1-\mathrm{Ha}$ haplotypes, as presented in Table 3, adopted the strategy of numbering applied in our recently published study on genetic interrelationship of European populations of F. magna [13]. The newly determined haplotypes of North American $F$. magna respected the numbering of the mentioned work and continuously proceeded in numbering new haplotypes. Since three cox 1 (CO1-Ha2, 4, and 5) and four nad1 (ND1-Ha1, 2, 5, and 7) haplotypes were detected
Table 2 Analysis of molecular variance (AMOVA) of population structure of North American Fascioloides magna

\begin{tabular}{|c|c|c|c|}
\hline \multirow[b]{3}{*}{ Grouping criterion } & \multicolumn{3}{|c|}{ Fst $(\operatorname{cox} 1+$ nad 1$)$} \\
\hline & \multicolumn{3}{|c|}{ Variance } \\
\hline & d.f. & components & Percent \\
\hline \multicolumn{4}{|l|}{ Five enzootic regions } \\
\hline Among groups & 4 & 0.968 & $18.25^{\mathrm{a}}$ \\
\hline Among populations within groups & 6 & 2.946 & 55.55 \\
\hline Within populations & 209 & 1.390 & 26.20 \\
\hline
\end{tabular}

\section{Structured populations}

$(A B, B C, O R)(M S, L A)(F L, G A)$

(SC) (MN) (QC, NL)

Among groups

Among populations within groups

$\begin{array}{ccc}5 & 4.149 & \mathbf{7 2 . 9 9} \\ 5 & 0.145 & 2.56 \\ 209 & 1.390 & \mathbf{2 4 . 4 5}\end{array}$

Within populations

24.45

Codes of US states, Canadian provinces and enzootic regions are explained in Table 1; AB, BC, OR - RMT and NPC enzootic regions; MS, LA $-1^{\text {st }}$ group of SAS region; $\mathrm{FL}, \mathrm{GA}-2^{\text {nd }}$ group of SAS; SC $-3^{\text {rd }}$ group of SAS; $\mathrm{MN}-\mathrm{GLR}$ region; QC, NL - NQL region; Fst, F-statistics; d.f., degrees of freedom; ${ }^{\text {insignificant }}$ results $(P>0.05)$; results significant at $P<0.001$ are in bold; results significant at $\mathrm{P}<0.05$ are in italics

exclusively in the European populations of the parasite [13] they are not presented in Table 3.

Of 43 polymorphic sites detected in cox 1 (transitions (ts)/transversions (tv) ratio; 40/3), 36 substitutions were not responsible for change in amino acid sequence while seven mutations underwent the non-synonymous substitutions. As for nad1, 16 substitutions out of 23 (ts/tv ratio; 19/4) were silent whereas seven mutations changed the amino acid sequence. The concatenated dataset of both $\operatorname{cox} 1$ and nad1 sequences (789 bp) contained 222 sequences that resulted in 50 haplotypes (Table 4; Fig. 1). The concatenated dataset contained 63 variable characters, of which 42 characters were parsimony-informative.

Phylogenetic analysis revealed two major clades (Fig. 2), one comprising samples from western enzootic regions, Rocky Mountain trench (RMT) and northern Pacific coast (NPC) (Canadian provinces $\mathrm{BC}, \mathrm{AB}$, and US state OR) (Fig. 2, clade B) whereas the second clade comprised samples from eastern enzootic regions, specifically the Great Lakes region (GLR) (US state MN), Gulf coast, lower Mississippi, and southern Atlantic seaboard enzootic region (SAS) (US states MS, LA, SC, GA, FL) and northern Quebec and Labrador (NQL) (Canadian provinces QC and NL) (Fig. 2, clade A).

The spectrum of definitive hosts sampled in the western enzootic regions was limited to three cervid hosts: wapiti, Roosevelt elk, and black-tailed deer. The respective samples of the western clade (US state OR, Canadian provinces $A B$ and $B C$ ) were characterized by single cervid hosts; $\mathrm{AB} /$ wapiti, $\mathrm{BC} /$ Roosevelt elk, and OR/blacktailed deer (Table 1). However, as evident from the 
Table 3 The cox1 (CO1-Ha) and nad1 (ND1-Ha) haplotypes identified for Fascioloides magna from North American localities

\begin{tabular}{|c|c|c|c|c|c|c|}
\hline $\begin{array}{l}\text { Country/province, } \\
\text { state }\end{array}$ & $\begin{array}{l}\text { cox1 haplotype } \\
\text { code }\end{array}$ & GenBank Acc. no. & $\begin{array}{l}\text { No. of specimens } \\
\text { CO1-Ha freq. - \% }\end{array}$ & $\begin{array}{l}\text { nad1 haplotype } \\
\text { code }\end{array}$ & GenBank Acc. no. & $\begin{array}{l}\text { No. of specimens } \\
\text { ND1-Ha freq. - \% }\end{array}$ \\
\hline \multirow[t]{2}{*}{ Canada/Alberta (AB) } & $\mathrm{CO} 1-\mathrm{Ha} 1 / \mathrm{AB}$ & GU599861 ${ }^{\text {a }}$ & $95 \rightarrow 38.3(\mathrm{Ha} 1)$ & ND1-Ha3/AB & GU599845 & $90 \rightarrow 39.6(\mathrm{Ha} 3)$ \\
\hline & $\mathrm{CO} 1-\mathrm{Ha} / \mathrm{AB}$ & GU599871 ${ }^{a}$ & $26 \rightarrow 10.5(\mathrm{Ha} 6)$ & ND1-Ha8/AB & GU599846 & $11 \rightarrow 4.8(\mathrm{Ha} 8)$ \\
\hline Canada/British & $\mathrm{CO} 1-\mathrm{Ha} 1 / \mathrm{BC}$ & KP635011 & & ND1-Ha3/BC & KP635037 & \\
\hline \multirow[t]{3}{*}{ Columbia (BC) } & CO1-Ha20/BC & KP635012 & $3 \rightarrow 1.2(\mathrm{Ha} 20)$ & ND1-Ha24/BC & KP635038 & $6 \rightarrow 2.6(\mathrm{Ha} 24)$ \\
\hline & CO1-Ha21/BC & KP635013 & $5 \rightarrow 2.0(\mathrm{Ha} 21)$ & ND1-Ha25/BC & KP635039 & $3 \rightarrow 1.3(\mathrm{Ha} 25)$ \\
\hline & & & & ND1-Ha30/BC & KP635040 & $1 \rightarrow 0.4(\mathrm{Ha} 30)$ \\
\hline Canada/Northern & CO1-Ha9/NL/QC & KP635014, KP635017 & $14 \rightarrow 5.6(\mathrm{Ha} 9)$ & ND1-Ha12/QC & KP635041 & $11 \rightarrow 4.8(\mathrm{Ha} 12)$ \\
\hline Quebec (QC) and & CO1-Ha17NL/QC & KP635015, KP635018 & $10 \rightarrow 4.0(\mathrm{Ha} 17)$ & ND1-Ha19/QC/NL & KP635042, KP635047 & $25 \rightarrow 11.0$ (Ha19) \\
\hline \multirow[t]{4}{*}{ Labrador (NL) } & CO1-Ha18/NL & KP635016 & $1 \rightarrow 0.4(\mathrm{Ha} 18)$ & ND1-Ha20/QC/NL & KP635043, KP635048 & $6 \rightarrow 2.6(\mathrm{Ha} 20)$ \\
\hline & $\mathrm{CO} 1-\mathrm{Ha} 22 / \mathrm{QC}$ & KP635019 & $5 \rightarrow 2.0(\mathrm{Ha} 22)$ & ND1-Ha21/QC & KP635044 & $2 \rightarrow 0.9(\mathrm{Ha} 21)$ \\
\hline & CO1-Ha28/QC & KP635020 & $2 \rightarrow 0.8(\mathrm{Ha} 28)$ & ND1-Ha22/QC/NL & KP635045, KP635049 & $4 \rightarrow 1.8$ (Ha22) \\
\hline & & & & ND1-Ha23/QC & KP635046 & $1 \rightarrow 0.4(\mathrm{Ha} 23)$ \\
\hline USA/Oregon (OR) & $\mathrm{CO} 1-\mathrm{Ha} 1 / \mathrm{OR}$ & GU599862 ${ }^{a}$ & & ND1-Ha3/OR & GU599848 & \\
\hline \multirow[t]{5}{*}{ USA/Minnesota (MN) } & CO1-Ha8/MN & GU599873 ${ }^{\mathrm{a}}$ & $13 \rightarrow 5.2(\mathrm{Ha} 8)$ & ND1-Ha9/MN & GU599849 & $7 \rightarrow 3.1(\mathrm{Ha9})$ \\
\hline & CO1-Ha9/MN & GU599874 & & ND1-Ha10/MN & GU599850ª & $12 \rightarrow 5.3(\mathrm{Ha} 10)$ \\
\hline & $\mathrm{CO} 1-\mathrm{Ha} 10 / \mathrm{MN}$ & GU599875 a & $4 \rightarrow 1.6(\mathrm{Ha} 10)$ & ND1-Ha11/MN & GU599851 $1^{a}$ & $2 \rightarrow 0.9(\mathrm{Ha} 11)$ \\
\hline & CO1-Ha11/MN & GU599876 & $3 \rightarrow 1.2(\mathrm{Ha} 11)$ & ND1-Ha12/MN & GU599852 & \\
\hline & CO1-Ha19/MN & KP635021 & $1 \rightarrow 0.4$ (Ha19) & ND1-Ha32/MN & KP635050 & $1 \rightarrow 0.4$ (Ha32) \\
\hline \multirow[t]{5}{*}{ USA/Mississippi (MS) } & CO1-Ha9/MS & KP635022 & & ND1-Ha12/MS & KP635051 & \\
\hline & $\mathrm{CO} 1-\mathrm{Ha} 12 / \mathrm{MS}$ & GU599877 & $2 \rightarrow 0.8(\mathrm{Ha} 12)$ & ND1-Ha15/MS & GU599855 & $2 \rightarrow 0.9(\mathrm{Ha} 15)$ \\
\hline & CO1-Ha13/MS & GU599878 a & $1 \rightarrow 0.4(\mathrm{Ha} 13)$ & ND1-Ha16/MS & GU599856 a & $2 \rightarrow 0.9(\mathrm{Ha} 16)$ \\
\hline & CO1-Ha14/MS & GU599879 a & $1 \rightarrow 0.4(\mathrm{Ha} 14)$ & ND1-Ha17/MS & GU599857 $7^{a}$ & $5 \rightarrow 2.2(\mathrm{Ha} 17)$ \\
\hline & CO1-Ha15/MS & GU599880 & $3 \rightarrow 1.2(\mathrm{Ha} 15)$ & & & \\
\hline \multirow[t]{4}{*}{ USA/Florida (FL) } & $\mathrm{CO} 1-\mathrm{Ha} 16 / \mathrm{FL}$ & GU599882 & $22 \rightarrow 8.9(\mathrm{Ha} 16)$ & ND1-Ha13/FL & GU599853 ${ }^{a}$ & $15 \rightarrow 6.6(\mathrm{Ha} 13)$ \\
\hline & & & & ND1-Ha14/FL & GU599854 & $2 \rightarrow 0.9(\mathrm{Ha} 14)$ \\
\hline & & & & ND1-Ha27/FL & KP635052 & $3 \rightarrow 1.3(\mathrm{Ha} 27)$ \\
\hline & & & & ND1-Ha28/FL & KP635053 & $2 \rightarrow 0.9(\mathrm{Ha} 28)$ \\
\hline \multirow[t]{2}{*}{ USA/Georgia (GA) } & $\mathrm{CO} 1-\mathrm{Ha} 7 / \mathrm{GA}$ & GU599872 ${ }^{\mathrm{a}}$ & $1 \rightarrow 0.4(\mathrm{Ha} 7)$ & ND1-Ha9/GA & GU599847 $7^{a}$ & \\
\hline & CO1-Ha16/GA & KP635023 & & ND1-Ha13/GA & KP635054 & \\
\hline USA/Louisiana (LA) & CO1-Ha15/LA & GU599881 ${ }^{a}$ & & ND1-Ha10/LA & KP635055 & \\
\hline
\end{tabular}


Table 3 The $\operatorname{cox} 1(\mathrm{CO} 1-\mathrm{Ha})$ and nad1 (ND1-Ha) haplotypes identified for Fascioloides magna from North American localities (Continued)

\begin{tabular}{|c|c|c|c|c|c|c|}
\hline & CO1-Ha29/LA & KP635024 & $1 \rightarrow 0.4(\mathrm{Ha} 29)$ & ND1-Ha12/LA & KP635056 & \\
\hline & CO1-Ha30/LA & KP635025 & $1 \rightarrow 0.4(\mathrm{Ha} 30)$ & ND1-Ha16/LA & GU599858 & \\
\hline & CO1-Ha31/LA & KP635026 & $1 \rightarrow 0.4(\mathrm{Ha} 31)$ & ND1-Ha17/LA & KP635057 & \\
\hline & CO1-Ha32/LA & KP635027 & $1 \rightarrow 0.4(\mathrm{Ha} 32)$ & ND1-Ha18/LA & GU599859 & $2 \rightarrow 0.9(\mathrm{Ha} 18)$ \\
\hline & $\mathrm{CO} 1-\mathrm{Ha} 33 / \mathrm{LA}$ & KP635028 & $2 \rightarrow 0.8(\mathrm{Ha} 33)$ & & & \\
\hline & CO1-Ha34/LA & KP635029 & $1 \rightarrow 0.4(\mathrm{Ha} 34)$ & & & \\
\hline \multirow[t]{7}{*}{ USA/South Carolina (SC) } & $\mathrm{CO} 1-\mathrm{Ha} 3 / \mathrm{SC}$ & KР635030 & $7 \rightarrow 2.8(\mathrm{Ha} 3)$ & $\mathrm{ND} 1-\mathrm{Ha} 4 / \mathrm{SC}$ & KP635058 & $2 \rightarrow 0.9(\mathrm{Ha} 4)$ \\
\hline & $\mathrm{CO} 1-\mathrm{Ha} 23 / \mathrm{SC}$ & KP635031 & $16 \rightarrow 6.5(\mathrm{Ha} 23)$ & ND1-Ha6/SC & KP635059 & $5 \rightarrow 2.2(\mathrm{Ha} 6)$ \\
\hline & $\mathrm{CO} 1-\mathrm{Ha} 24 / \mathrm{SC}$ & KP635032 & $1 \rightarrow 0.4(\mathrm{Ha} 24)$ & ND1-Ha19/SC & KP635060 & \\
\hline & $\mathrm{CO} 1-\mathrm{Ha} 25 / \mathrm{SC}$ & KP635033 & $1 \rightarrow 0.4(\mathrm{Ha} 25)$ & ND1-Ha26/SC & KP635061 & $1 \rightarrow 0.4(\mathrm{Ha} 26)$ \\
\hline & $\mathrm{CO} 1-\mathrm{Ha} 26 / \mathrm{SC}$ & KP635034 & $1 \rightarrow 0.4(\mathrm{Ha} 26)$ & ND1-Ha29/SC & KP635062 & $3 \rightarrow 1.3(\mathrm{Ha} 29)$ \\
\hline & $\mathrm{CO} 1-\mathrm{Ha} 27 / \mathrm{SC}$ & KP635035 & $2 \rightarrow 0.8(\mathrm{Ha} 27)$ & ND1-Ha31/SC & KP635063 & $1 \rightarrow 0.4(\mathrm{Ha} 31)$ \\
\hline & CO1-Ha35/SC & KP635036 & $1 \rightarrow 0.4(\mathrm{Ha} 35)$ & & & \\
\hline
\end{tabular}

Frequency (freq.) of haplotypes were calculated for all individuals having the respective Ha despite of their locality; numbering of haplotypes follows that of Králová-Hromadová et al. [13], therefore Ha numbers of

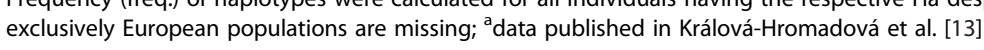


Table 4 Details on concatenated haplotypes (cox $1+$ nad 1$)$ of North American Fascioloides magna individuals

\begin{tabular}{|c|c|c|c|}
\hline $\begin{array}{l}\text { Concatenated } \\
\text { haplotype }\end{array}$ & $\begin{array}{l}\text { US state, } \\
\text { CA province }\end{array}$ & $\begin{array}{l}\text { cox1 } \\
\text { haplotype }\end{array}$ & $\begin{array}{l}\text { nad } 1 \\
\text { haplotype }\end{array}$ \\
\hline Ha1 & $\mathrm{AB}, \mathrm{BC}, \mathrm{OR}$ & $\mathrm{CO} 1-\mathrm{Ha} 1$ & ND1-Ha3 \\
\hline $\mathrm{Ha} 2$ & $A B$ & $\mathrm{CO} 1-\mathrm{Ha} 1$ & ND1-Ha8 \\
\hline Ha3 & $A B$ & CO1-Ha6 & ND1-Ha3 \\
\hline $\mathrm{Ha} 4$ & $B C$ & $\mathrm{CO} 1-\mathrm{Ha} 21$ & ND1-Ha3 \\
\hline $\mathrm{Ha} 5$ & $B C$ & $\mathrm{CO} 1-\mathrm{Ha} 2 \mathrm{O}$ & ND1-Ha30 \\
\hline Ha6 & $B C$ & $\mathrm{CO} 1-\mathrm{Ha} 1$ & ND1-Ha24 \\
\hline Ha7 & $B C$ & $\mathrm{CO} 1-\mathrm{Ha} 21$ & $\mathrm{ND} 1-\mathrm{Ha} 24$ \\
\hline Ha8 & $B C$ & $\mathrm{CO} 1-\mathrm{Ha} 20$ & ND1-Ha25 \\
\hline Ha9 & $B C$ & $\mathrm{CO} 1-\mathrm{Ha} 1$ & ND1-Ha25 \\
\hline Ha10 & OR & CO1-Hal & ND1-Ha3 \\
\hline Ha11 & $\mathrm{MN}$ & CO1-Ha19 & ND1-Ha9 \\
\hline Ha12 & $\mathrm{MN}$ & $\mathrm{CO} 1-\mathrm{Ha} 8$ & ND1-Ha32 \\
\hline Ha13 & $\mathrm{MN}$ & CO1-Ha11 & ND1-Ha9 \\
\hline Ha14 & $\mathrm{MN}$ & $\mathrm{CO} 1-\mathrm{Ha} 10$ & ND1-Ha9 \\
\hline Ha15 & $\mathrm{MN}$ & $\mathrm{CO} 1-\mathrm{Ha} 10$ & ND1-Ha11 \\
\hline Ha16 & $\mathrm{MN}$ & $\mathrm{CO} 1-\mathrm{Ha} 8$ & $\mathrm{ND} 1-\mathrm{Ha} 10$ \\
\hline Ha17 & $N L, Q C$ & CO1-Ha17 & ND1-Ha19 \\
\hline Ha18 & $N L, Q C$ & CO1-Ha9 & ND1-Ha20 \\
\hline Ha19 & $\mathrm{NL}$ & CO1-Ha18 & ND1-Ha19 \\
\hline $\mathrm{Ha} 20$ & QC & $\mathrm{CO} 1-\mathrm{Ha} 22$ & ND1-Ha23 \\
\hline $\mathrm{Ha} 21$ & QC & $\mathrm{CO} 1-\mathrm{Ha} 28$ & ND1-Ha12 \\
\hline $\mathrm{Ha} 22$ & $\mathrm{NL}, \mathrm{QC}$ & CO1-Ha22 & ND1-Ha22 \\
\hline $\mathrm{Ha} 23$ & QC & CO1-Ha17 & $\mathrm{ND} 1-\mathrm{Ha} 21$ \\
\hline $\mathrm{Ha} 24$ & $\mathrm{MN}, \mathrm{QC}$ & CO1-Ha9 & $\mathrm{ND} 1-\mathrm{Ha} 12$ \\
\hline $\mathrm{Ha} 25$ & MS & $\mathrm{CO} 1-\mathrm{Ha} 12$ & ND1-Ha15 \\
\hline $\mathrm{Ha} 26$ & MS & CO1-Ha13 & ND1-Ha17 \\
\hline $\mathrm{Ha} 27$ & MS & CO1-Ha14 & ND1-Ha17 \\
\hline $\mathrm{Ha} 28$ & MS, LA & CO1-Ha15 & ND1-Ha16 \\
\hline $\mathrm{Ha} 29$ & MS & $\mathrm{CO} 1-\mathrm{Ha} 9$ & ND1-Ha17 \\
\hline Ha30 & MS & CO1-Ha15 & ND1-Ha12 \\
\hline Ha31 & LA & CO1-Ha32 & ND1-Ha12 \\
\hline Ha32 & $L A$ & $\mathrm{CO} 1-\mathrm{Ha} 29$ & ND1-Ha17 \\
\hline Ha33 & $L A$ & CO1-Ha30 & ND1-Ha12 \\
\hline Ha34 & LA & CO1-Ha34 & $\mathrm{ND} 1-\mathrm{Ha} 10$ \\
\hline Ha35 & LA & CO1-Ha33 & ND1-Ha18 \\
\hline Ha36 & $L A$ & CO1-Ha31 & ND1-Ha17 \\
\hline Ha37 & SC & $\mathrm{CO} 1-\mathrm{Ha} 24$ & ND1-Ha31 \\
\hline На38 & SC & $\mathrm{CO} 1-\mathrm{Ha} 25$ & ND1-Ha19 \\
\hline Ha39 & SC & $\mathrm{CO} 1-\mathrm{Ha} 23$ & ND1-Ha19 \\
\hline $\mathrm{Ha} 40$ & $\mathrm{SC}$ & CO1-Ha3 & ND1-Ha6 \\
\hline Ha41 & SC & $\mathrm{CO} 1-\mathrm{Ha} 26$ & ND1-Ha6 \\
\hline $\mathrm{Ha} 42$ & SC & CO1-Ha35 & ND1-Ha29 \\
\hline $\mathrm{Ha} 43$ & SC & $\mathrm{CO} 1-\mathrm{Ha} 27$ & ND1-Ha29 \\
\hline
\end{tabular}

Table 4 Details on concatenated haplotypes (cox $1+$ nad 1$)$ of North American Fascioloides magna individuals (Continued)

\begin{tabular}{llll}
\hline $\mathrm{Ha} 44$ & $\mathrm{SC}$ & $\mathrm{CO} 1-\mathrm{Ha} 3$ & ND1-Ha4 \\
$\mathrm{Ha} 45$ & $\mathrm{SC}$ & $\mathrm{CO} 1-\mathrm{Ha} 23$ & ND1-Ha26 \\
$\mathrm{Ha} 46$ & $\mathrm{FL}$ & $\mathrm{CO} 1-\mathrm{Ha} 16$ & ND1-Ha14 \\
$\mathrm{Ha} 47$ & $\mathrm{FL}, \mathrm{GA}$ & $\mathrm{CO} 1-\mathrm{Ha} 16$ & ND1-Ha13 \\
$\mathrm{Ha} 48$ & $\mathrm{FL}$ & $\mathrm{CO} 1-\mathrm{Ha} 16$ & ND1-Ha27 \\
$\mathrm{Ha} 49$ & $\mathrm{FL}$ & $\mathrm{CO} 1-\mathrm{Ha} 16$ & ND1-Ha28 \\
$\mathrm{Ha} 50$ & $\mathrm{GA}$ & $\mathrm{CO} 1-\mathrm{Ha}$ & ND1-Ha9 \\
\hline
\end{tabular}

Codes of US states and Canadian (CA) provinces are explained in Table 1;

details on individual CO1-Ha and ND1-Ha are presented in Table 3

internal structure of the phylogenetic clade B, the interrelationships of western $F$. magna population were not related to cervid host species.

The second dominant phylogenetic clade (clade A) of eastern enzootic regions was polyphyletic. Some of the respective sublineages within clade A mirror the geography/host pattern. The most homogenous internal lineages were no. 2 (GLR-Minnesota; white-tailed deer), nos. 4 and 6 (SAS-Louisiana, Mississippi; wapiti), and no. 7 (SAS-South Carolina; white-tailed deer) (Fig. 2). One specimen from Georgia (SAS) (Ha50, lineage 3), clustered separately. Lineage no. 9 was created by haplotypes specific to SAS (US states SC, FL, GA) and two hosts; wapiti and white-tailed deer. On the other hand, lineage nos. 1 and 8 were heterologous; haplotypes within these lineages corresponded to F. magna from geographically distant regions - SAS and NQL. Even more diverse was lineage no. 5, which included representatives of all eastern populations: SAS, NQL and GLR. Additionally, besides heterogeneity in geography, the three heterologous lineages $(1,5$ and 8 ) were characterized by the most diverse spectrum of definitive hosts - wapiti, caribou, muskox and white-tailed deer (Fig. 2).

The mitochondrial network also revealed frequent sharing of haplotypes between western enzootic regions NPC and RMT, and relative isolation of populations from Minnesota and Florida (Fig. 3). Although haplotypes specific for SAS and NQL did not create separate clusters in the network, haplotypes of these two eastern enzootic regions were not shared among different geographic areas. The only exception was Ha24, which was shared between MN (GLR) and QC (NQL) (Table 4). Regardless, samples from different locations within SAS had very little overlap. Haplotypes were shared within but not among three groups (SC + FL, GA, MS + LA) with one exception of shared haplotype between Florida and Georgia. On the contrary, populations in the northeastern enzootic focus (NQL) shared most of their haplotypes between Quebec and Labrador despite different host origin (caribou and muskox). Surprising overlap in haplotypes was detected for individuals from Minnesota 


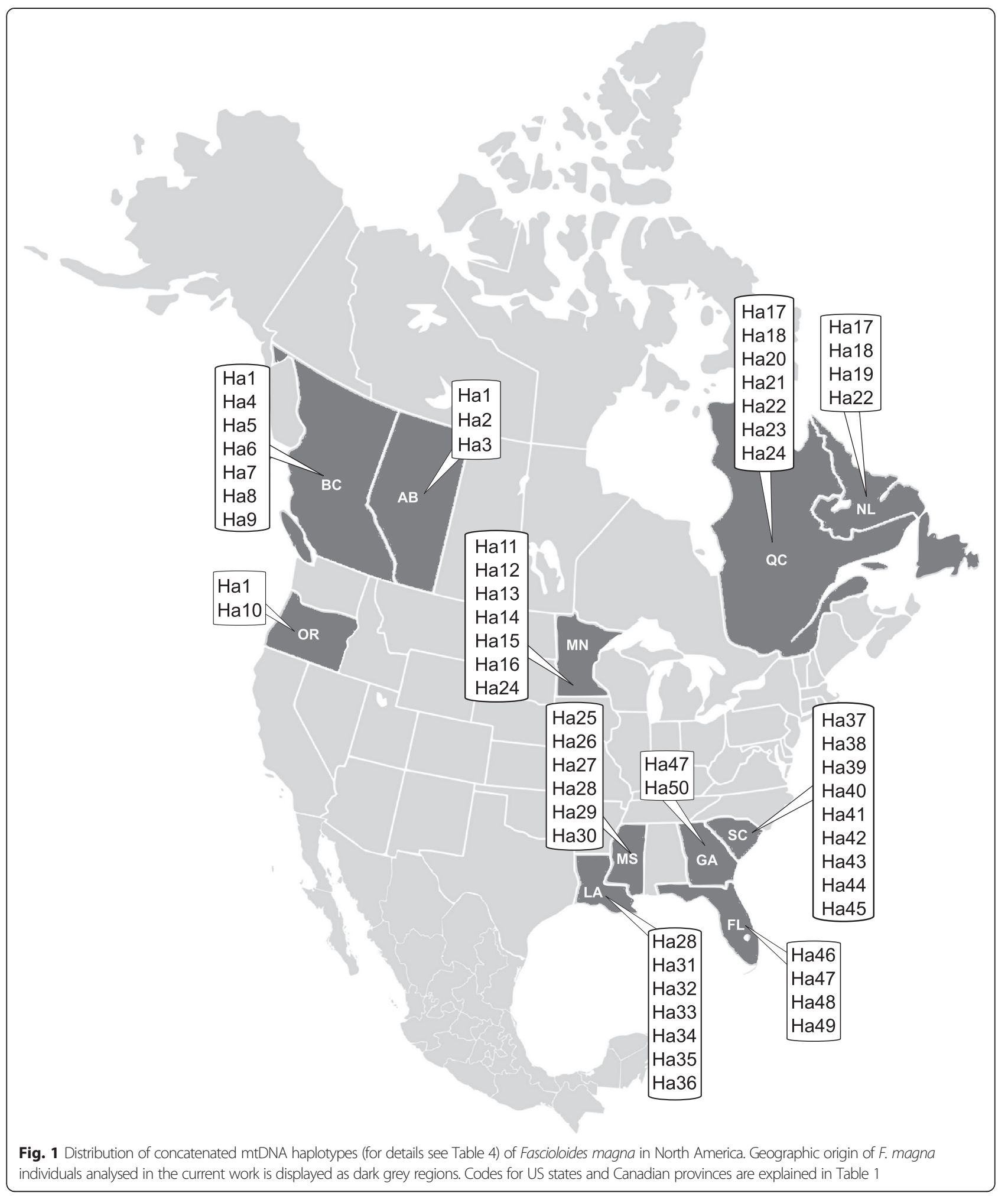

(GLR) and Quebec (NQL). Other haplotypes did not cluster according to host origin either. For example haplotypes were shared among wapiti and black-tailed deer in Alberta and Oregon.
The AMOVA analysis reflects the pattern obtained from phylogenetic analysis and haplotype network. Populations grouped according to their enzootic membership explained very little variance in the data, whereas 


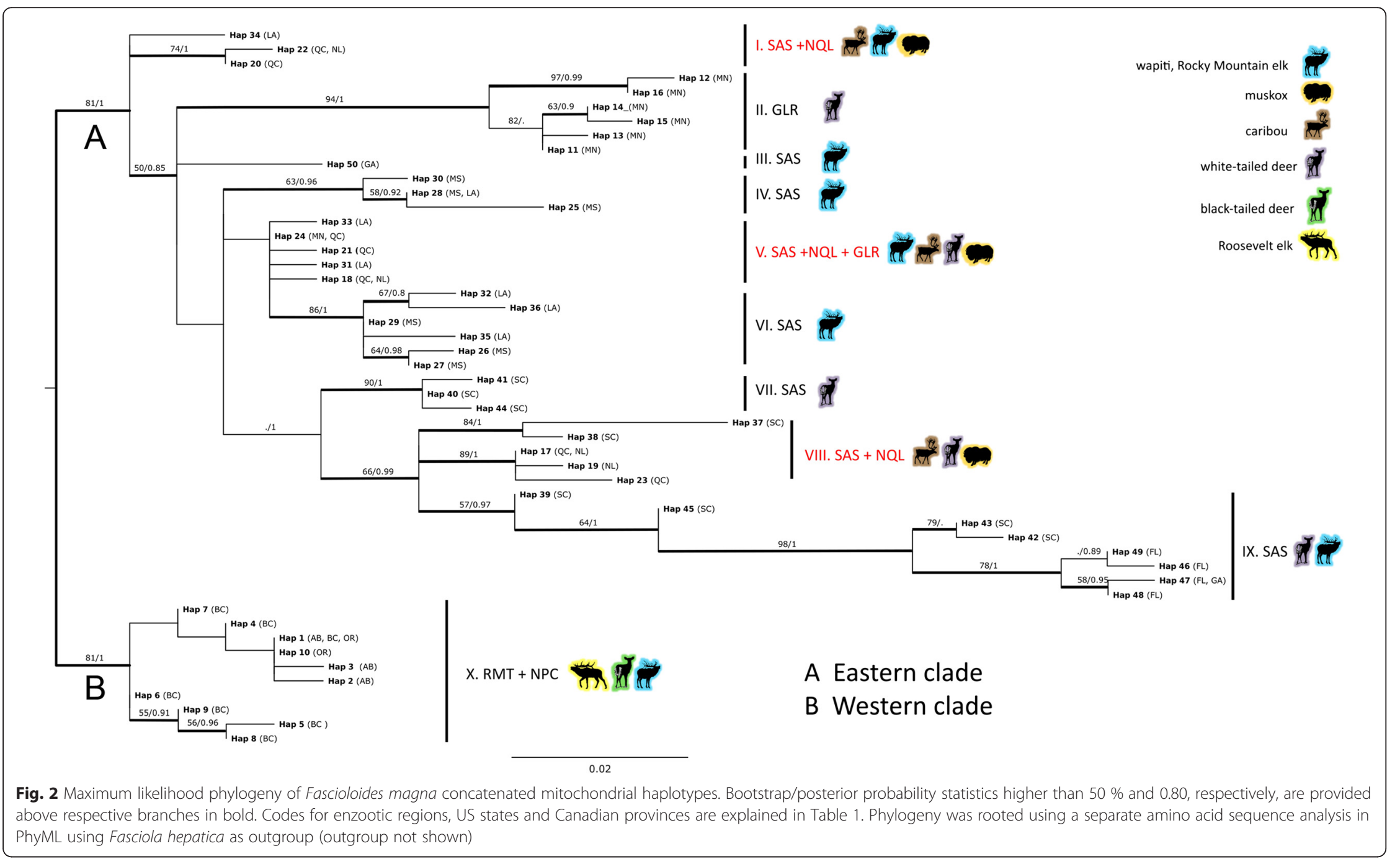




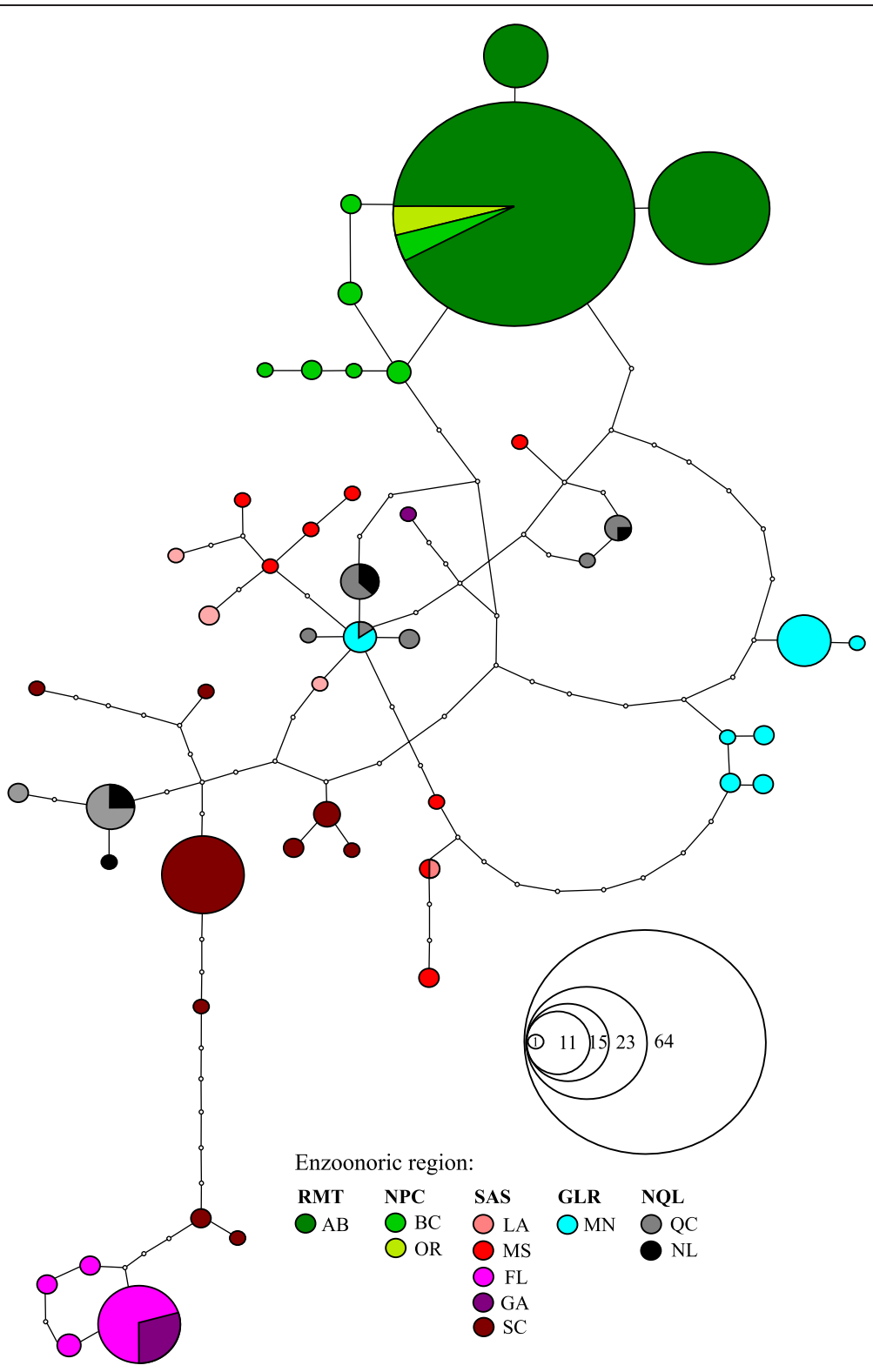

Fig. 3 Haplotype network of Fascioloides magna populations obtained in TCS. Each haplotype is represented by a circle scaled according to the number of specimens. Empty circles along the mutation pathways represent putative unsampled haplotypes. Codes for enzootic regions, US states and Canadian provinces are explained in Table 1

Table 5 Molecular variability and neutrality tests for six defined North American areas of Fascioloides magna

\begin{tabular}{llllllll}
\hline Area & S. size & No. Ha & Hd & Pi & Tajima's D & Fu and Li's D & Fu and Li's F \\
\hline NPC+RMT (AB, BC, OR) & 110 & 9 & 0.61 & 0.0011 & -0.504 & 1.112 & 0.676 \\
SAS1 (LA, MS) & 15 & 11 & 0.96 & 0.0074 & -0.584 & -0.505 & -0.606 \\
SAS2 (FL, GA) & 23 & 5 & 0.57 & 0.0029 & $-1.733^{\mathrm{a}}$ & $\mathbf{- 2 . 8 8 3}$ & $\mathbf{- 2 . 9 6 0}$ \\
SAS3 (SC) & 28 & 9 & 0.70 & 0.0065 & -0.317 & 0.242 & 0.077 \\
GLR (MN) & 21 & 7 & 0.79 & 0.0066 & 0.637 & 1.208 & 1.209 \\
NQL (QC, NL) & 25 & 8 & 0.83 & 0.0078 & 1.256 & 1.232 & 1.449 \\
\hline
\end{tabular}

Codes of US states and Canadian provinces are explained in Table 1; S. size, sample size; No. Ha, number of haplotypes; Hd, haplotype diversity; Pi, nucleotide diversity; ${ }^{a}$ results significant at $\mathrm{P}<0.05$; results significant at $\mathrm{P}<0.01$ are in bold 
variance in data within the areas was much higher (Table 2). On the contrary, populations organized into six groups according to the distribution of the haplotypes explained almost $73 \%$ of the variance at the highest level (among areas), whereas less than $3 \%$ was left among populations within the areas. Characterization of the same six groups performed in DNASP revealed some differences. Most of the population groups had similar levels of $H d$ and Pi diversities and non-significant results of neutrality tests (Table 5 ). Only the western population $(\mathrm{AB}, \mathrm{BC}, \mathrm{OR})$ and the SAS2 group (FL, GA) had lower values of $H d$ and $P i$. The SAS2 group also had significantly negative values in all three tests of neutrality. Negative values of neutrality tests usually are interpreted as an indication of population expansion after a bottleneck or a selective sweep (e.g., [25]).

\section{Discussion}

Current data provide a complete picture of the genetic structure of $F$. magna populations from all enzootic regions in North America (NA); the Rocky Mountain trench (RMT), the northern Pacific coast (NPC), northern Quebec and Labrador (NQL), the Great Lakes region (GLR), and the Gulf coast, lower Mississippi, and southern Atlantic seaboard (SAS). The most straightforward finding was explicit genetic separation of western (NPC and RMT) and eastern (NQL, GLR and SAS) populations of the parasite.

Parasites in general rely almost entirely on their hosts for dispersal ranging from small to large scales [3]. The geographical distributions of most parasite species are limited by the distributions of potential host species or by environmental constraints on the parasite's rates of development [26]. The population genetic structure of a parasite, and consequently its ability to adapt to a given host, is strongly linked to its own life history as well as the life history of its host [27]. From this point of view, relationships of genetically and demographically variable hosts and parasites should be studied in direct collaboration [4].

The genetic structure of NA giant liver fluke populations needs to be related to the historical and current distribution of obligate definitive NA cervid hosts of F. magna, in particular wapiti, white-tailed deer, and caribou. According to Pybus [6], current NA populations of $F$. magna are separated in detached pockets across North America and the parasite may have co-evolved with the ancestral Odocoileus spp. Giant liver fluke has originally been widespread in white-tailed deer in major wetland habitats throughout NA where wapiti and caribou sympatric with white-tailed deer encountered F. magna in overlapping contaminated regions.

The distinction of two mitochondrial lineages of $F$. magna corresponds very probably to historical distribution, extirpation, re-introduction, and current occurrence of two obligate definitive hosts of giant liver fluke; white-tailed deer in eastern and wapiti in the western part of NA. Odocoileus spp. is native to North America and its populations were well established in the southeastern USA during the Pleistocene epoch [28]. In the early part of the $19^{\text {th }}$ century unrestricted hunting, deforestation and extensive agricultural development led to dramatic declines in the white-tailed deer populations in the south-eastern USA [29]. Implementation of an extensive restocking programme during the late $19^{\text {th }}$ and in $20^{\text {th }}$ century increased the white-tailed deer populations, especially in the south-east where re-establishing deer populations was considered essential [30].

On the other hand, wapiti is of Eurasian origin and represents phylogenetically the most derived "old world deer", which displayed different migratory routes to the NA continent with the postglacial reopening of the passage southward from Beringia into the mid-continent [31]. Generally, wapiti were extirpated from the Rocky Mountains of Alberta and British Columbia by the early 1900 s and reduced to a few remnant populations in isolated areas. In the first half of the $20^{\text {th }}$ century, wapiti were restocked from the Yellowstone National Park and expanded in number and geographic distribution within the Banff National Park (BNP). A significant exchange of wapiti between BNP and Kootenay National Park through Vermilion Pass provided a natural dispersal mechanism for F. magna from British Columbia into Alberta (see [32] and references therein).

Western populations of wapiti and populations of white-tailed deer in the eastern part of NA are separated by an expansive area of dry grasslands (the Great Plains region) throughout the core of Canada and USA, with very limited ecological conditions suitable for maintaining the giant liver fluke. Consequently, western and eastern populations of $F$. magna might be separated on a historical timeframe and evolved distinct genetic structure. Alternatively, the apparent western and eastern $F$. magna population structure may be a result of the lack of suitable cervid hosts following widespread extirpation of ungulate populations in eastern and central NA following European colonization that may also reduce the opportunity for genetic admixing among local $F$. magna populations [6]. The effect on population segregation has been documented by studies of mtDNA phylogeography in white-tailed deer $[30,33]$ as well as two other hosts of F. magna, the blacktailed deer [34] and caribou [35]. However, we find the historical separation more probable. The effect of such a recent bottleneck ( $<200$ years ago) would have to be extremely strong to produce reciprocal monophyly between the two population clades A and B. Furthermore, we would expect to see strongly reduced numbers of haplotypes in local populations of F. magna. Neither the diversity of obtained haplotypes (Fig. 3) nor the results of neutrality tests (Table 5) point to such a scenario. 
Phylogenetic reconstruction of the relationships between concatenated mtDNA haplotypes using Maximum Likelihood and Bayesian Inference, as well as haplotype network reflecting genealogical information congruently revealed genetic admixture of $F$. magna individuals from geographically distant eastern populations of the parasite (NQL, GLR, SAS), where overlapping distribution of white-tailed deer and caribou may have played an important role. Caribou were present in North America as early as the glacial periods of the middle Pleistocene in Beringia [36]. In the $19^{\text {th }}$ century, peripheral populations of caribou within the United States were extirpated and populations that occurred from Minnesota to Maine, in New York, Wisconsin and Michigan disappeared [37, 38]. While white-tailed deer was widespread in major wetland habitats throughout NA, eastern populations of caribou ranged as far south as Alabama in eastern NA [39] and overlapped with white-tailed deer in the Great Lakes region [40, 41]. Consequently, caribou sympatric with white-tailed deer could have encountered F. magna in overlapping contaminated wetland habitats, thus facilitating its movement into new areas and establishing new parasite populations. The present fluke population in caribou in the northeast (NQL) is most probably a residual population that survived the caribou extirpations in more southern regions. In addition, giant liver fluke further spilled over into local muskox populations that were overlapping with infected caribou in NQL region.

In contrast to the general pattern of mixing in the eastern populations, some populations seem to retain genetic distinctiveness. For example, all but one haplotype from Florida and Georgia created a separate cluster in the haplotype network (Fig. 3). Despite the samples originated from wapiti, which was probably introduced to the area recently, white-tailed deer was the naturally occurring host in the past. In the mitochondrial analysis by Ellsworth et al. [30] the populations of O. virginianus from south Florida showed genetic differentiation attributable to pleistocene climatic oscillations [30]. Thus, current genetic patterns of the parasite in the same region may be remnants of past population structure the host. In relation to that it is noteworthy that the FL + GA fluke population was the only one where significantly negative values of neutrality tests were seen (Table 5 ).

Pertinent to the genetic relatedness of western populations of giant liver fluke (NPC and RMT) confirmed by statistical testing (AMOVA analysis) and phylogenetic analyses (Maximum Likelihood and Bayesian Inference), the distribution of six populations (subspecies) of Cervus elaphus in North America [41] needs to be considered. The Roosevelt elk population $(C$. e. roosevelti) along the Pacific coast of British Columbia and US states Washington/ Oregon (NPC enzootic region) is immediately adjacent to the Rocky Mountain elk (C. e. canadensis) population in the
RMT enzootic region. The Coastal Mountains to the west (where the Roosevelt elk originated) are separated from the Rocky Mountains to the east (origin of Rocky Mountain elk) only by a broad lowland area (the Interior Plateau) [41], which provides an extensive network of contiguous forests, wetlands, lakes and rivers. This biotope offers shared habitats for different populations of wapiti in western enzootic regions NPC and RMT and also suitable environmental conditions for perpetuation of $F$. magna populations. The current shared genetic makeup of the western populations of F. magna could be explained by admixing of the fluke population in association with distribution of different wapiti subspecies in this region.

Based on the mitochondrial data, it can be concluded that there are no signs of host specificity of $F$. magna adults towards any definitive host species; the detected haplotypes of giant liver fluke are shared amongst several host species in adjacent populations. Similar genetic patterns of geographic isolation with shared hosts broadly displayed e.g., winter ticks Dermacentor albipictus on cervids in North America [42], suggests widespread patterns of historic factors directly affecting multiple host parasite relationships.

\section{Conclusion}

Genetically diverse NA populations of $F$. magna reflect historical distribution, past extirpation, subsequent reintroduction, and current occurrence of the obligate definitive cervid hosts of giant liver fluke. The present study provides missing pieces of the puzzle and completes the comprehensive dataset on mitochondrial structure and population diversity of all (NA and European) F. magna populations. Comparison of original results with published data [13] revealed the following. Since North America is the original continent of F. magna, a high level of molecular diversity in mitochondrial haplotypes evident between and within respective enzootic regions was anticipated. While the total number of concatenated haplotypes in NA populations ranged from three (RMT) and eight (each in NQL and NPC) to 26 (SAS) (present study) only two haplotypes were determined in Danube floodplain forests and four in each of Italy and the Czech Republic [13]. As expected, lower genetic heterogeneity was determined in newly established natural foci after introduction of non-indigenous species and the bottleneck effect is evident (data not shown).

The only haplotype common for parasites from both continents was haplotype 1 , assessed in F. magna from Italy, Alberta, and Oregon, thus confirming the western NA origin of fascioloidosis in the first European focus - Italy [13]. After comparison of present data with data achieved for European F. magna samples [13] two additional haplotypes (Ha40, Ha44; Table 4) detected in specimens from South Carolina (SAS) were identical with European samples from the Czech Republic and Danube floodplain 
forests (data not shown). This provides the first indication of the likely origin of the Czech focus of fascioloidosis. However, detailed study of genetic interrelationships of global F. magna populations should be assessed by multilocus population genetic markers, such as microsatellites, polymorphic and codominant markers which were recently designed specifically for giant liver fluke [43] and can provide more detailed population structuring.

\section{Competing interests}

The authors declare that they have no competing interests.

\section{Authors' contributions}

$\mathrm{EB}$ and IKH conceived the research outline and aims of the work. EB performed experimental work (DNA extraction, PCR amplification, PCR product purification, analyses of sequence data) and wrote the draft of the manuscript. IKH designed and managed the whole study, participated in analyses of sequence data, and critically reviewed the whole manuscript. JS performed statistical and phylogenetic analyses, constructed the phylogenetic tree and network phylogram, and wrote the corresponding parts of the manuscript. GM and SB sequenced the PCR products and revised the manuscript. MP provided the parasitic material, contributed to the outline of the manuscript in relation to distribution of cervid hosts and provided English language corrections. All authors read and approved the final manuscript.

\section{Acknowledgements}

We wish to convey our acknowledgement and indebtedness to the following colleagues for providing F. magna samples: Frank Phillips (Government Newfoundland, Quebec, Canada); Joseph Townley (Nunatsiavut Government, Newfoundland and Labrador, Canada); Don Robertson, Lorrie Dyer, Lyle Wilcox and Reg Dyer (Vancouver Island University, Canada); Vasyl Tkach (University of North Dakota, Grand Forks, North Dakota, USA); Kevin M. Keel (College of Veterinary Medicine, University of Georgia, Athens, USA); Dale Pulis (St.-Cloud, Minnesota, USA). We also express our gratitude to the Warden Service in Banff National Park, Alberta, Canada. This work was supported by the Slovak Grand Agency VEGA (project VEGA no. 2/0133/13), EU $7^{\text {th }}$ Framework programme MODBIOLIN project No. 316304, and as implementation of the project Centre of Excellence for Parasitology (ITMS26220120022) supported by the Research and Development Operational Programme funded by the European Regional Development Fund (rate 0.1)

Note Nucleotide sequence data reported in this paper are available in the GenBank ${ }^{\mathrm{T} M}, \mathrm{EMBL}$ and DDBJ databases under the accession numbers KP635011 - KP635063.

\section{Author details \\ ${ }^{1}$ Institute of Parasitology, Slovak Academy of Sciences, Hlinkova 3, 04001 Košice, Slovakia. ${ }^{2}$ Biology Centre AS CR, Institute of Parasitology and Faculty of Science, University of South Bohemia, Branišovská 31, 37005 České Budějovice, Czech Republic. ${ }^{3}$ Department of Molecular Biology, Faculty of Natural Sciences, Comenius University, Mlynská dolina B-2, 84215 Bratislava, Slovakia. ${ }^{4}$ Geneton Ltd., Ilkovičova 3, 84104 Bratislava, Slovakia. ${ }^{5}$ Alberta Fish and Wildlife Division and Department of Biological Sciences, University of Alberta, Edmonton, AB, Canada.}

\section{Received: 16 April 2015 Accepted: 11 May 2015}

Published online: 28 May 2015

\section{References}

1. Prugnolle F, Liua H, de Meeu T, Ballouxa F. Population genetics of complex life-cycle parasites: an illustration with trematodes. Int J Parasitol. 2005;35:255-63.

2. Štefka J, Hypša V, Scholz T. Interplay of host specificity and biogeography in the population structure of a cosmopolitan endoparasite: microsatellite study of Ligula intestinalis (Cestoda). Mol Ecol. 2009;18:1187-206.
3. Poulin R, Krasnov BR, Mouillot D, Thieltges DW. The comparative ecology and biogeography of parasites. Philos Trans R Soc Lond B Biol Sci. 2011;366:2379-90.

4. Renaud F, Clayton D, de Meeüs T. Biodiversity and evolution in host-parasite associations. Biodivers Conserv. 1996;5:963-74.

5. Salzet M, Capron A, Stefano GB. Molecular crosstalk in host-parasite relationships: schistosome and leech host interactions. Parasitol Today. 2000;16:536-40.

6. Pybus MJ. Liver flukes. In: Samuel WM, Pybus MJ, Kocan AA, editors. Parasitic Diseases of Wild Mammals. 2nd ed. lowa: lowa State University Press, Ames; 2001.

7. Králová-Hromadová I, Bazsalovicsová E, Demiaszkiewicz A. Molecular characterization of Fascioloides magna (Trematoda: Fasciolidae) from south-western Poland based on mitochondrial markers. Acta Parasitol. 2015;60:544-7.

8. Marinković $D$, Kukolj V , Aleksić-Kovačević S, Jovanović M, Knežević M. The role of hepatic myofibroblasts in liver cirrhosis in fallow deer (Dama dama) naturally infected with giant liver fluke (Fascioloides magna). BMC Vet Res. 2013;9:45.

9. Erhardová-Kotrlá B. The occurrence of Fascioloides magna (Bassi, 1875) in Czechoslovakia. Prague: Academia Publishing House of the Czechoslovak Academy of Sciences; 1971

10. Rajský D, Patus A, Bukovjan K. Prvý nález Fascioloides magna (Bassi, 1875) na Slovensku. Slovenský veterinárny časopis. 1994;19:29-30. In Slovak.

11. Faltýnková A, Horáčková E, Hirtová L, Novobilský A, Modrý D, Scholz T. Is Radix peregra a new intermediate host of Fascioloides magna (Trematoda) in Europe? Field and experimental evidence. Acta Parasitol. 2006;51:87-90.

12. Rajský D, Čorba J, Várady M, Špakulová M, Cabadaj R. Control of fascioloidosis (Fascioloides magna Bassi, 1875) in red deer and roe deer. Helminthologia. 2002;39:67-70.

13. Králová-Hromadová I, Bazsalovicsová E, Štefka J, Špakulová M, Vávrová S, Szemes T, et al. Multiple origins of European populations of the giant liver fluke Fascioloides magna (Trematoda: Fasciolidae), a liver parasite of ruminants. Int J Parasitol. 2011:41:373-83.

14. Králová-Hromadová I, Špakulová M, Horáčková E, Turčeková L’, Novobilský A, Beck $R$, et al. Sequence analysis of ribosomal and mitochondrial genes of the giant liver fluke Fascioloides magna (Trematoda: Fasciolidae): intraspecific variation and differentiation from Fasciola hepatica. J Parasitol. 2008:94:58-67.

15. Werle E, Schneider C, Renner M, Volker M, Fiehn W. Convenient singlestep, one tube purification of PCR products for direct sequencing. Nucleic Acids Res. 1994;22:4354-5.

16. Garey JR, Wolstenholme DR. Platyhelminth mitochondrial DNA: Evidence for early evolutionary origin of a tRNA (serAGN) that contains a dihydrouridine arm replacement loop, and of serine-specifying AGA and AGG codons. J Mol Evol. 1989:28:374-87.

17. Ohama T, Osawa S, Watanabe K, Jukes TH. Evolution of the mitochondrial genetic code. IV. AAA as an asparagine codon in some animal mitochondria. J Mol Evol. 1990;30:329-32.

18. Gouy M, Guindon S, Gascuel O. SeaView Version 4: a multiplatform graphical user interface for sequence alignment and phylogenetic tree building. Mol Biol Evol. 2010;27:221-4.

19. Guindon S, Dufayard JF, Lefort V, Anisimova M, Hordijk W, Gascuel O. New Algorithms and Methods to Estimate Maximum-Likelihood Phylogenies: Assessing the Performance of PhyML 3.0. Syst Biol. 2010;59:307-21.

20. Ronquist F, Teslenko M, Van Der Mark P, Ayres DL, Darling A, Höhna S, et al. MrBayes 3.2: Efficient Bayesian phylogenetic inference and model choice across a large model space. Syst Biol. 2012:61:539-42.

21. Lanfear R, Calcott B, Ho SYW, Guindon S. PartitionFinder: combined selection of partitioning schemes and substitution models for phylogenetic analyses. Mol Biol Evol. 2012;29:1695-701.

22. Clement M, Posada D, Crandall KA. TCS: a computer program to estimate gene genealogies. Mol Ecol. 2000;9:1657-9.

23. Excoffier L, Lischer HEL. Arlequin suite ver 3.5: a new series of programs to perform population genetics analyses under Linux and Windows. Mol Ecol Resour. 2010;10:564-7.

24. Librado P, Rozas J. DnaSP v5: a software for comprehensive analysis of DNA polymorphism data. Bioinformatics. 2009;25:1451-2.

25. Fu YX. Statistical tests of neutrality of mutations against population growth hitchhiking, and background selection. Genetics. 1997;147:915-25.

26. Dobson A, Carper R. Global Warming and Potential changes in Host-Parasite and Disease-Vector Relationships. In: Peters RL, Lovejoy TE, editors. Global warming and biodiversity. New Haven, CT: Yale University Press; 1992. p. 201-17. 
27. van Schaik J, Kerth G, Bruyndonckx N, Christe P. The effect of host social system on parasite population genetic structure: comparative population genetics of two ectoparasitic mites and their bat hosts. BMC Evol Biol. 2014;14:18.

28. Roth JA, Laerm J. A late Pleistocene vertebrate assemblage from Edisto Island. SC Brimleyana. 1980:3:1-29.

29. Noble RE. Mississippi deer herd: past and present. Mississippi Game and Fish. 1966;29:14-5.

30. Ellsworth DL, Honeycutt RL, Silvy NJ, Bickham JW, Klimstra WD. Historical biogeography and contemporary patterns of mitochondrial DNA variation in white-tailed deer from the Southeastern United States. Evolution. 1994:48:122-36.

31. Burns JA. Mammalian faunal dynamics in Late Pleistocene Alberta. Canada Quatern Int. 2010;217:37-42.

32. Pybus MJ, Butterworth EW, Woodes JG. An expanding population of giant liver fluke (Fascioloides magna) in elk (Cervus canadensis) and other ungulates in Canada. J Wildl Dis. 2015;51:431-5.

33. Cullingham Cl, Merrill EH, Pybus MJ, Bollinger TK, Wilson GA, Coltman DW. Broad and fine-scale analysis of white-tailed deer populations: estimating the relative risk of chronic wasting disease spread. Evol Appl. 2011:4:116-31.

34. Latch EK, Heffelfinger JR, Fike JA, Rhodes Jr OE. Species-wide phylogeography of North American mule deer (Odocoileus hemionus): cryptic glacial refugia and postglacial recolonization. Mol Ecol. 2009;18:1730-45.

35. McDevitt AD, Mariani S, Hebblewhite M, Decesare NJ, Morgantini L, Seip D, et al. Survival in the Rockies of an endangered hybrid swarm from diverged caribou (Rangifer tarandus) lineages. Mol Ecol. 2009;18:665-79.

36. Kurtén B, Anderson E. Pleistocene mammals of North America. New York: Columbia University Press; 1980

37. Cringan AT. History, food habits and range requirements of the woodland caribou of continental North America. T N Am Wildl Nat Res. 1957:22:485-501.

38. Heinselman ML. Fire in the Virgin Forests of the Boundary Waters Canoe Area. Minnesota Quaternary Res. 1973;3:329-82.

39. Churcher CS, Parmalee PW, Bell GL, Lamb JP. Caribou from the late Pleistocene of northwestern Alabama. Can J Zool. 1989:67:1210-6.

40. Banfield AWF. The mammals of Canada. Toronto: University of Toronto Press; 1974.

41. Bryant LD, Maser C. Classification and distribution. In: Thomas JW, Toweil DE, editors. Elk of North America. Harrisburg: PA: Stackpole Books; 1982. p. 1-59.

42. Leo S, Samuel WM, Pybus MJ, Sperling FD. Origin of Dermacentor albipictus (Acari: Ixodidae) on elk in the Yukon. Canada J Wildl Dis. 2014;50:544-51.

43. Minárik G, Bazsalovicsová E, Zvijáková L', Štefka J, Pálková L, KrálováHromadová I. Development and characterization of multiplex panels of polymorphic microsatellite loci in giant liver fluke Fascioloides magna (Trematoda: Fasciolidae), using next-generation sequencing approach. Mol Biochem Parasitol. 2014:195:30-3.

\section{Submit your next manuscript to BioMed Central and take full advantage of:}

- Convenient online submission

- Thorough peer review

- No space constraints or color figure charges

- Immediate publication on acceptance

- Inclusion in PubMed, CAS, Scopus and Google Scholar

- Research which is freely available for redistribution 